\title{
Penggunaan Plastik Daur Ulang Sebagai Kemasan Sabun Tangan Cair Di Muhammadiyah Kramat Jati, Jakarta Timur (KMK No. HK.01.07-Menkes-382-2020 Tentang Protokol Kesehatan Bagi Masyarakat di Tempat dan Fasilitas Umum Dalam Rangka Pencegahan Covid-19)
}

\author{
Marjan Miharja, Erwin Syahruddin, Saparuli, Viktor Agung Pratama, Heru Mahendra, Ronal Saut, \\ Hardian \& Salamat Martua \\ Sekolah Tinggi Ilmu Hukum IBLAM
}

\begin{abstract}
The more single-use plastic is used, the higher the possibility of increasing plastic waste in the environment. Chemicals in plastics can endanger living things and humans, plastic / inorganic waste is still very minimal management. so that the use of used or recycled plastics as packaging or containers of liquid soap must be carried out to preserve the environment. To overcome this problem, Group 2 Community Service (PKM) STIH IBLAM will implement the use of recycled or used plastic bottles as hand soap packaging. Currently the Indonesian people are facing challenges that require human resources to adapt to the Corona Virus Disease 2019 (COVID-19) pandemic situation. Health, social and economic aspects must go hand in hand and support each other in order to achieve the expected goals. It is hoped that through the use of recycled or used plastic bottles as hand soap packaging it can help economically, socially, and maintain health during the COVID-19 pandemic. The results obtained from this activity are the use of recycled or used plastic bottles as hand soap packaging can reduce costs compared to using single-use plastic bottles and protect the environment from plastic waste which is difficult to decompose. Empowering the community for economic and social sustainability, as well as implementing health protocols in efforts to prevent and control COVID-19 in accordance with the Decree of the Minister of Health of the Republic of Indonesia Number Hk.01.07 / Menkes / 382/2020 concerning Health Protocols for Communities in Places and Public Facilities in the Context of Prevention and Control of Corona Virus Disease 2019 (Covid-19).
\end{abstract}

Keywords: Plastic recycle, liquid hand soap, Covid-19, Jakarta

\section{Pendahuluan}

Pengabdian kepada Masyarakat, adalah kegiatan yang berorientasi pada pelayanan masyarakat dan penerapan ilmu pengetahuan teknologi dan seni terutama dalam menyelesaikan permasalahan masyarakat dan memajukan kesejahteraan bangsa . Pengabdian masyarakat dimasa pandemi sebagai wujud kepedulian mahasiswa STIH IBLAM Jakarta dalam kehidupan sosial untuk membantu masyarakat beradaptasi dengan situasi pandemi Corona Virus Disease 2019 (COVID-19). Dalam menghadapi adaptasi kebiasaan baru menuju masyarakat yang produktif dan aman terhadap Corona Virus Disease 2019 (COVID -19), diperlukan penataan penyelenggaraan berbagai kegiatan dengan prioritas kesehatan masyarakat.

Published by:

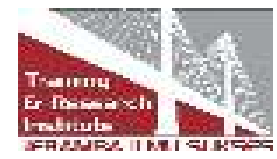


Sesuai dengan jurusan dari Sekolah Tinggi yang kami tekuni sekarang, kami coba melihat kembali Aspek Hukum Penanganan Penyebaran Covid-19, yang mana Kesehatan adalah salah satu kebutuhan dasar manusia, yang belakangan telah dijamin haknya secara konstitusional. Melalui Perubahan Kedua Undang-Undang Dasar 1945, kesehatan ditegaskan sebagai bagian dari hak asasi manusia. Dalam Pasal 28H ayat (1) dinyatakan, bahwa: "Setiap orang berhak hidup sejahtera lahir dan batin, bertempat tinggal, dan mendapat lingkungan hidup yang baik dan sehat serta berhak memperoleh pelayanan kesehatan." Masuknya ketentuan tersebut ke dalam Undang-Undang Dasar 1945, menggambarkan perubahan paradigma yang luar biasa. Kesehatan dipandang tidak lagi sekedar urusan pribadi yang terkait dengan nasib atau karunia Tuhan yang tidak ada hubungannya dengan tanggung jawab negara,melainkan suatu hak hukum (legal rights) yang tentunya dijamin oleh Negara.

Dengan melaksanakan protokol kesehatan sesuai dengan Keputusan Menteri Kesehatan Republik Indonesia Nomor Hk.01.07/Menkes/382/2020 Tentang Protokol Kesehatan Bagi Masyarakat Di Tempat Dan Fasilitas Umum Dalam Rangka Pencegahan Dan Pengendalian Corona Virus Disease 2019 (Covid-19). Sebagai acuan bagi kementerian/lembaga, pemerintah daerah provinsi, pemerintah daerah kabupaten/kota, dan masyarakat termasuk asosiasi, pengelola, pemilik, pekerja, dan pengunjung pada tempat dan fasilitas umum, serta komponen lain, baik dalam penetapan kebijakan, pembinaan aktivitas usaha, pelaksanaan usaha/kegiatan, aktivitas masyarakat, maupun dalam melakukan pengawasan kegiatan di tempat dan fasilitas umum, dalam rangka mencegah terjadinya episenter/kluster baru selama masa pandemi COVID-19.

Salah satu upaya untuk mengurangi dampak buruk sampah plastik bagi lingkungan adalah dengan melaksanakan prinsip 3R dalam kehidupan sehari-hari, yaitu pengurangan pemakaian (reduce), pemakaian ulang (reuse), dan pendaur ulang (recycle). Kemasan atau packaging adalah suatu wadah yang menempati suatu barang agar aman, menarik, mempunyai daya pikat bagi seseorang yang ingin membeli suatu produk (Mukhtar dan Nurif, 2015). Salah satu yang dibutuhkan masyarakat dimasa pandemi COVID-19 ini, sabun tangan cair yang pengemasannya menggunan plastik. Kebutuhan akan sabun tangan cair semakin meningkat untuk kegiatan-kegiatan sosial dalam rangka pencegahan dan pengendalian corona virus disease 2019 (covid-19). Maka di tuntut untuk meningkatkan produktivitas dan kualitas produknya.

Proses produksi merupakan kegiatan utama para mitra dalam menghasilkan produk. Tingkat efektifitas dan efisiensi berproduksi dituntut memiliki nilai yang tinggi. Mitra harus beroperasi secara efektif dan dapat memenuhi tingkat kebutuhan produksi yang ditargetkan. Kualitas merupakan salah satu hal penting dalam proses produksi. Mitra harus menghasilkan kualitas produk yang sesuai dengan spesifikasi yang diinginkan, agar kepuasan masyarakat yang menggunakannya dapat tercapai. Pengawasan produk diimplementasikan sebagai jaminan pada masyarakat bahwa produk yang diterima memiliki mutu yang baik.

Dengan merebaknya pandemi COVID-19, para mitra juga harus mengatasi berbagai

Published by:

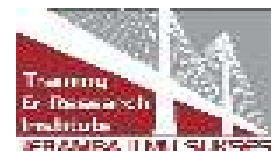


masalah penting yang dihadapi, termasuk WFH (Work From Home) dan pembatasan sosial. Saat seperti inilah para mitra harus meningkatkan fleksibilitas serta pengoptimalan SDM dan waktu operasinya. Agar dapat membantu para mitra untuk melanjutkan produksinya dalam tatanan kehidupan baru (new normal).

Pemilihan Mitra Kerja berdasarkan hasil observasi oleh Tim Pengusul, yang menurut Tim Pengusul memenuhi syarat sesuai Panduan Penelitian dan Pengabian kepada Masyarakat Simlitabmas RISTEK DIKTI tahun 2020. Program Pengabdian kepada masyarakat tahun 2020, melakukan kerjasama dengan 2 (dua) mitra. Adapun mitra program Pengabdian kepada Masyarakat (PKM) ini adalah sebagai berikut :

1) Pimpinan Cabang Muhammadiyah Kramat Jati yang beralamat Jl. Dewi Sartika No. 316 A RT. 008 RW. 04 Kelurahan Cawang Kecamatan KramatJati Jakarta Timur, DKI Jakarta.

2) Pimpinan Wilayah Pemuda Muhammadiyah yang beralamat Jl. Dewi Sartika No. 316 A RT. 008 RW. 04 Kelurahan Cawang Kecamatan Kramat Jati Jakarta Timur, DKI Jakarta.

Adapun rumusan masalah adalah bagaimana proses pembuatan dan penggunaan plastik daur ulang serta desain kemasan sabun tangan cair yang menarik, aman serta ramah lingkungan sesuai BPOM di era New Normal.

\section{Solusi Permasalahan}

Berdasarkan analisa tim pengusul, permasalahan yang ada pada para mitra mengenai produksi sabun tangan cair dan pengemasan. Prihal terkait proses produksi manual serta terbatasnya SDM (Sumber Daya Manusia) dan manajemen waktu produksi. Dari hasil wawancara kami dengan para mitra dalam PKM ini, berikut solusi permasalahan mitra :

Salah satu cara yang paling efektif untuk mengoptimalkan efisiensi para mitra adalah dengan memodernisasi proses dan mensistemasi alur kerja. Mitra perlu mengurangi pekerjaan-pekerjaan yang membuang banyak waktu dan tenaga, mengurangi pembuangan material, mengoptimalkan penggunaan peralatan produksi dengan meminimalkan kerusakan, dan menyederhanakan rantai pasokan. Sistem Enterprise Resource Planning (ERP) dapat memfasilitasi semua itu sehingga membantu produsen mencapai efisiensi yang optimal.

Perencanaan produksi, efisiensi waktu oleh mitra dimasa pandemi Covid-19 dilakukan dengan tujuan untuk dapat memproduksi (output) sabun tangan cair dan pengemasan dalam waktu tertentu dengan kuantitas dan kualitas yang dikehendaki serta bermanfaat bagi masyarakat. Serta dengan memperhatikan yang ada dalam masyarakat yaitu konsumen, pekerja, dan lingkungan sekitar mitra Muhammadiyah Kramat Jati. Sehingga para mitra dapat bekerja dengan kapasitas yang optimal, dan fasilitas produksi yang dimiliki mitra dapat digunakan sebaik-baiknya atau seefisien mungkin.

Dari beberapa solusi tersebut, diharapkan luaran yang akan dilakukan dalam pengabdian kepada masyarakat berupa produk sabun tangan cair dengan kemasan botol plastik hasil

Published by:

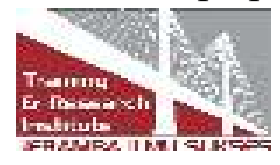


daur ulang. Selanjutnya kami sebagai mahasiswa ikut berpartisipasi pada kegiatankegiatan sosial dengan mensosialisasikan kepada masyarakat agar selalu melaksanakan protokol kesehatan sesuai dengan Keputusan Menteri Kesehatan Republik Indonesia Nomor Hk.01.07/Menkes/382/2020 Tentang Protokol Kesehatan Bagi Masyarakat Di Tempat Dan Fasilitas Umum Dalam Rangka Pencegahan Dan Pengendalian Corona Virus Disease 2019 (Covid-19). Kami sebagai mahasiswa juga dapat memberikan sumbangsih kepada negara dan masyarakat indonesia sesuai dengan kemampuan kami sebagai mahasiswa, melalui Jurnal yang akan kami terbitkan di JNPM ( Jurnal Nasional Pengabdian Masyarakat ). Kegiatan PKM akan kami infokan dikoran Republika dan Sindo Online, dan akan di upload di link Channel Youtube Kampus STIH IBLAM, Laporan Harian akan diserahkan dalam bentuk jurnal pada ketua PKM dan Laporan Akhir PKM akan kami lakukan dengan mengadakan Seminar di domisili Mitra PCM Kramat Jati, Jakarta Timur, DKI Jakarta

\section{Metode Pelaksanaan}

Metode pelaksanaan untuk mencapai tujuan dari Kegiatan Pengabdian Kepada Masyarakat ini dalam mengatasi masalah masyarakat untuk menghadapi kondisi new normal yang dilakukan oleh Tim Pengabdi adalah melaksanakan pembuatan sabun tangan cair dan desain pengemasannya yang kami buat bersama mitra PWPM DKI Jakarta dan PCM Kramat Jati. Produk dari hasil kegiatan PkM ini akan dibantu untuk dibagikan kepada masyarakat seki tar mitra kami berdomisili.

Permasalahan yang sama dari kedua Mitra Pimpinan Wilayah Pemuda Muhammdiyah DKI Jakarta dan Pimpinan Cabang Muhammadiyah Kramat Jati dalam proses Pembuatan Sabun Tangan Cair dan Pengemasannya, maka solusi yang kami hadirkan dalam dalam pelaksanaan kegiatan ini ada beberapa metode, sebagai berikut :

Tabel 1. Metode Pelaksanaan.

\begin{tabular}{|c|c|c|c|c|}
\hline No : & $\begin{array}{l}\text { ASPEK } \\
\text { PERMASALAHAN }\end{array}$ & PERMASALAHAN & $\begin{array}{l}\text { SOLUSI } \\
\text { PERMASALAHAN }\end{array}$ & $\begin{array}{l}\text { METODE } \\
\text { PELAKSANAAN }\end{array}$ \\
\hline 1 & Teknik Produksi & $\begin{array}{lr}\text { Teknik } & \text { proses } \\
\text { produksi } & \text { sabun } \\
\text { tangan cair, masih } \\
\text { menggunakan } \\
\text { manual cara } \\
\text { manusia) } & \text { (tenaga } \\
\text { kapasitas } & \text { produksing } \\
\text { tidak } & \text { dapat } \\
\text { maksimal } & \text { dan } \\
\text { efisien. } & \end{array}$ & $\begin{array}{l}\text { Dari permasalahan } \\
\text { tersebut cara yang } \\
\text { paling efektif untuk } \\
\text { mengoptimalkan } \\
\text { efisiensi para mitra } \\
\text { adalah dengan } \\
\text { memodernisasi } \\
\text { proses dan } \\
\text { mensistemasi alur } \\
\text { kerja. Mitra perlu } \\
\text { mengurangi } \\
\text { pekerjaan-pekerjaan } \\
\text { yang membuang } \\
\text { banyak waktu dan } \\
\text { tenaga, mengurangi }\end{array}$ & $\begin{array}{l}\text { Bahan-bahan sabun } \\
\text { tangan cair dan botol } \\
\text { kemasannya. } \\
\text { Pengoperasi an } 2 \\
\text { mesin mixer untuk } \\
\text { mengaduk bahan- } \\
\text { bahan sabun yang di } \\
\text { campur sampai } \\
\text { merata. } \\
\text { Monitoring cairan } \\
\text { untuk di Packaging } \\
\text { cairan sabun yang } \\
\text { telah di aduk } \\
\text { kedalam } \\
\text { botol } 500 \mathrm{ml} \text {. }\end{array}$ \\
\hline
\end{tabular}

Published by:

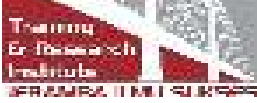




\begin{tabular}{|c|c|c|c|c|}
\hline & & & $\begin{array}{l}\text { pembuangan } \\
\text { material, } \\
\text { mengoptimalkan } \\
\text { penggunaan peralatan } \\
\text { produksi dengan } \\
\text { meminimalkan } \\
\text { kerusakan. }\end{array}$ & \\
\hline 2 & Manajemen Waktu & $\begin{array}{l}\text { Jadwal Proses } \\
\text { produksi, efisiensi } \\
\text { waktu } \\
\text { oleh mitra dimasa } \\
\text { pandemi Covid- } 19 \\
\text { belum terjadwal } \\
\text { sehingga } \\
\text { pelaksanaan proses } \\
\text { produksi tidak dapat } \\
\text { optimal sesuai } \\
\text { kapasitasnya. }\end{array}$ & $\begin{array}{l}\text { Perencanaan } \\
\text { produksi, efisiensi } \\
\text { waktu oleh mitra } \\
\text { dimasa pandemi } \\
\text { Covid-19 dilakukan } \\
\text { dengan tujuan untuk } \\
\text { dapat memproduksi } \\
\text { (output) sabun tangan } \\
\text { cair dan pengemasan } \\
\text { dalam waktu tertentu } \\
\text { dengan kuantitas dan } \\
\text { kualitas yang } \\
\text { dikehendaki } \\
\text { bermanfaat serta } \\
\text { masyarakat. bagi } \\
\text { Pentingnya } \\
\text { komunikasi dan } \\
\text { kordinasi dengan } \\
\text { mitra } \\
\text { sebelum proses } \\
\text { produksi dilakukan. }\end{array}$ & $\begin{array}{lr}\text { Penentuan } & \text { waktu } \\
\text { proses } & \text { produksi } \\
\text { sehingga } & \text { dapat } \\
\text { dilakukan } & \text { satu } \\
\text { waktu tertentu. }\end{array}$ \\
\hline 3 & $\begin{array}{l}\text { Manajemen Mutu } \\
\text { dan Kesehatan }\end{array}$ & $\begin{array}{l}\text { Tidak adanya } \\
\text { standarisasi } \\
\text { dosis/kadar bahan } \\
\text { baik yang telah jadi } \\
\text { cairan atau belum, } \\
\text { proses pembuatan } \\
\text { tidak menggunakan } \\
\text { sarung tangan } \\
\text { Sedangkan } \\
\text { menggunakan bahan } \\
\text { kimia dan pewarna } \\
\text { yang dapat juga } \\
\text { merusak sabun cair } \\
\text { yang dihasilkan, } \\
\text { standart bentuk dan } \\
\text { kebersihannya. }\end{array}$ & $\begin{array}{l}\text { Pemakaian } \\
\text { timbangan atau alat } \\
\text { ukur dan gelas kaca } \\
\text { untuk menuangkan } \\
\text { bahan- bahannya. } \\
\text { Pemakaian mesin } \\
\text { mixer } \\
\text { mengaduk untuk } \\
\text { merata. }\end{array}$ & $\begin{array}{l}\text { Menyiapkan } \\
\text { peralatan wadah, } \\
\text { alat ukur dan mesin, } \\
\text { untun proses } \\
\text { pembuatan sabun } \\
\text { tangan cair., }\end{array}$ \\
\hline
\end{tabular}

\section{Pelaksanaan Kegiatan}

Adapun Tahapan Pengabdian kepada Masyarakat ini, dilakukan dengan menggunakan beberapa tahapan sebagai berikut :

Published by:

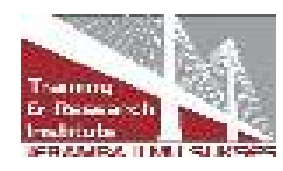


- Tahapan Persiapan, Observasi ke lokasi Pimpinan Cabang Muhammadiyah Kramat Jati dan Pemuda Muhammadiyah Kramat Jati.

- Mendapatkan arahan bimbingan dari Pimpinan Cabang Muhammadiyah Kramat Jati dan Pemuda muhammadiyah Kramat Jati mengenai kegiatan pengabdian kepada masyarakat yang akan dilaksanakan.

- Mengajukan Proposal Kegiatan PKM di STIH Iblam Kramat Raya,Jakarta Pusat.

- Menyiapkan bahan-bahan dan peralatan yang diperlukan dalam proses pembuatan sabun tangan cair dan pengemasannya.

- Membuat sabun tangan cair dan desain pengemasannya sesuai keilmuan dengan para mitra dari Pimpinan Cabang Muhammadiyah Kramat Jati dan Pemuda Muhammadiyah Kramat Jati.

- Perbaikan dan penyempurnaan sabun tangan cair dan desain kemasannya.

- Serah terima sabun tangan cair dalam kemasan kepada mitra Muhammadiyah Kramat Jati.

- Melaksanakan kegiatan-kegiatan sosial dilingkungan mitra Muhammadiyah Kramat Jati dan sekitarnya.

- Buku Catatan Harian Penelitian/Pengabdian dilaporkan keketua PKM.

- Laporan akhir Pengabdian kepada Masyarakat di Muhammadiyah kramat Jati.

- Seminar sosialisasi tentang Protokol Kesehatan bagi masyarakat di tempat dan fasilitas umum dalam rangka pencegahan COVID-19 dilokasi mitra Muhammadiyah Kramat Jati.

Kegiatan Pertama / Kamis ,13 November 2020

Bimbingan PKM (Ketua PKM Dr. Marjan Miharja, S.H.,M.H.)

Pengarahan Kegiatan PKM, cara pembuatan proposal PKM dan pengenalan mitra PCM Kramat Jati dan PWPM DKI Jakarta untuk kegiatan PKM. 


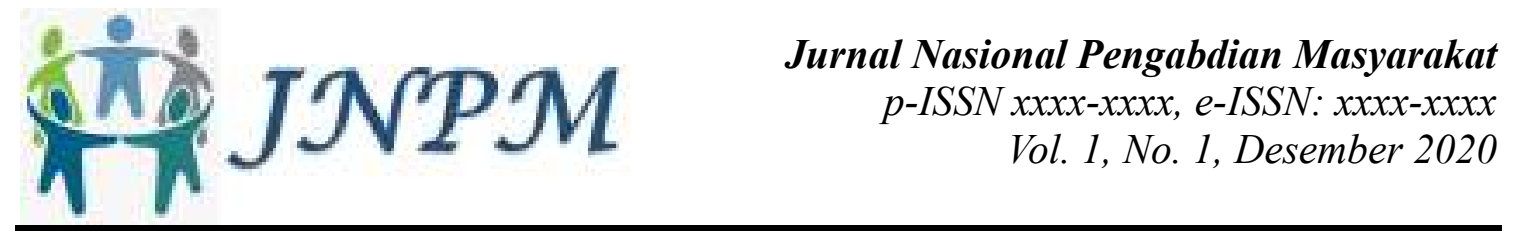

Gambar. 1

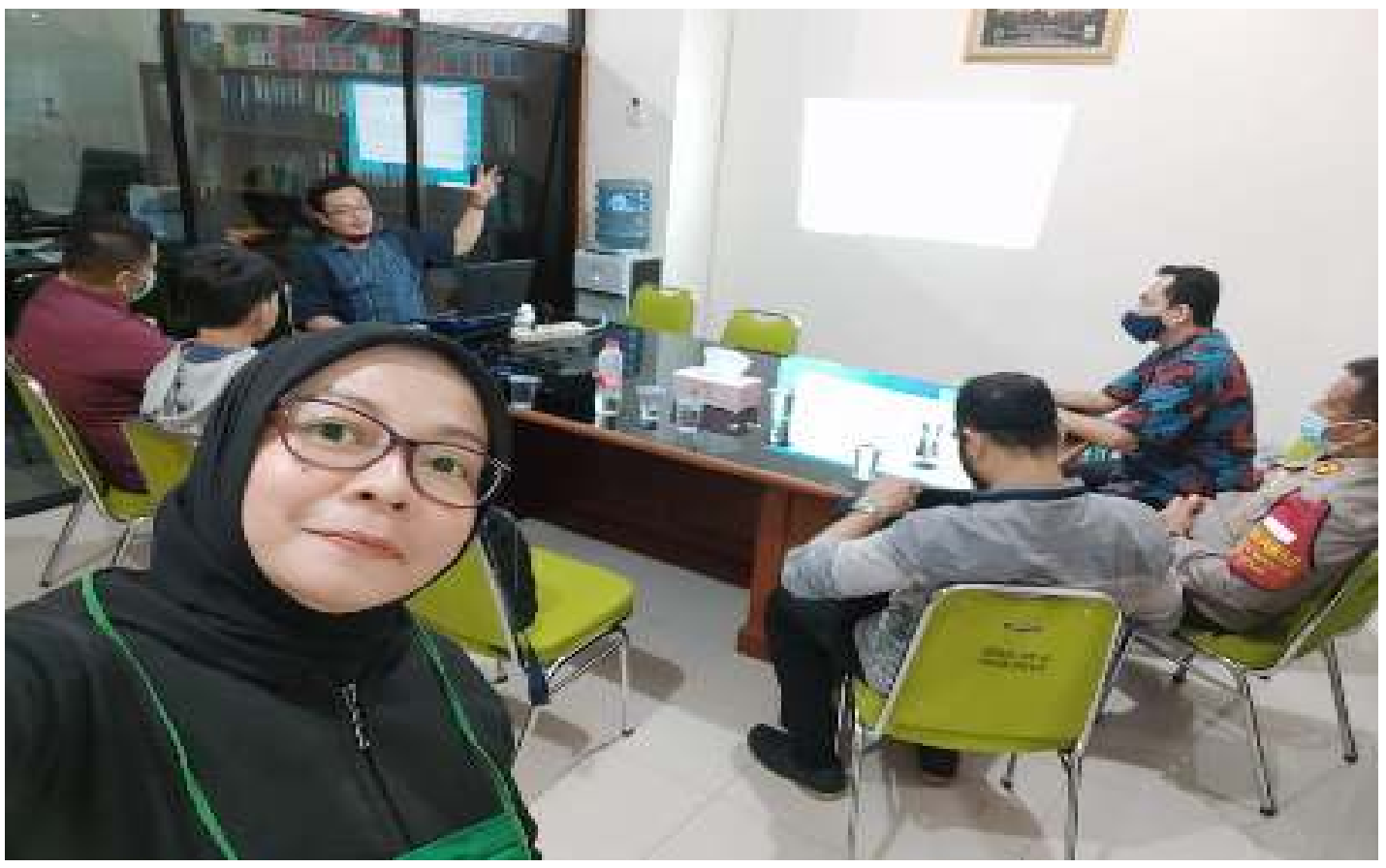

Kegiatan Kedua / Senin, 16 November 2020 Bimbingan PKM

(Ketua PKM Dr. Marjan Miharja, S.H.,M.H./ Apt. Guntur S.R , S.,Si.) Pengarahan tentang kemitraan dan produk yang dihasilkan, menjelaskan tentang luaran wajib yang akan dihasilkan.

Gambar. 2

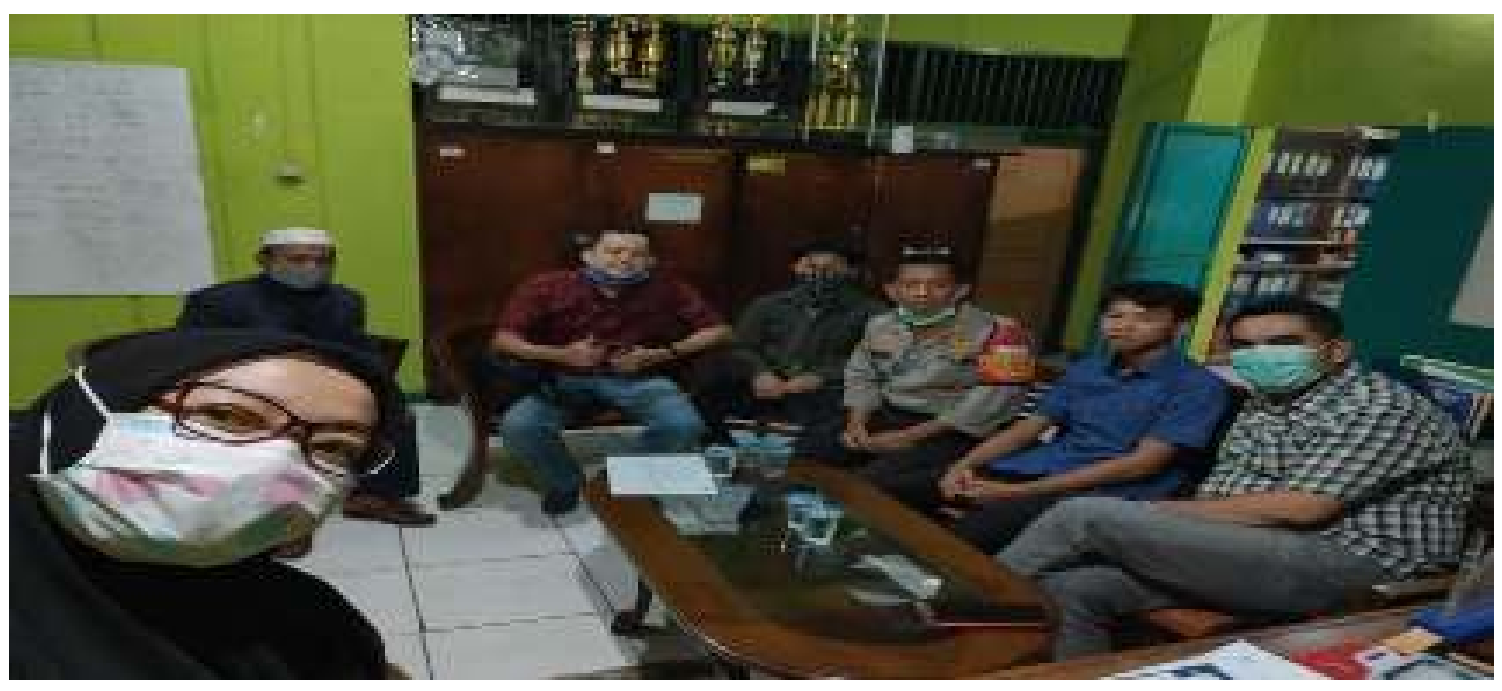

Published by:

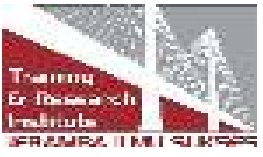




\section{Kegiatan Ketiga}

\section{Bimbingan PKM / Senin, 23 November 2020}

(Ketua PKM Dr. Marjan Miharja, S.H.,M.H./ PWPM DKI Jakarta Apt. Guntur S.R , S.,Si.)

Pengarahan tentang proses pembuatan sabun tangan cair dan pengemasannya serta penjelasan tentang komposisi produk.

Gambar 3

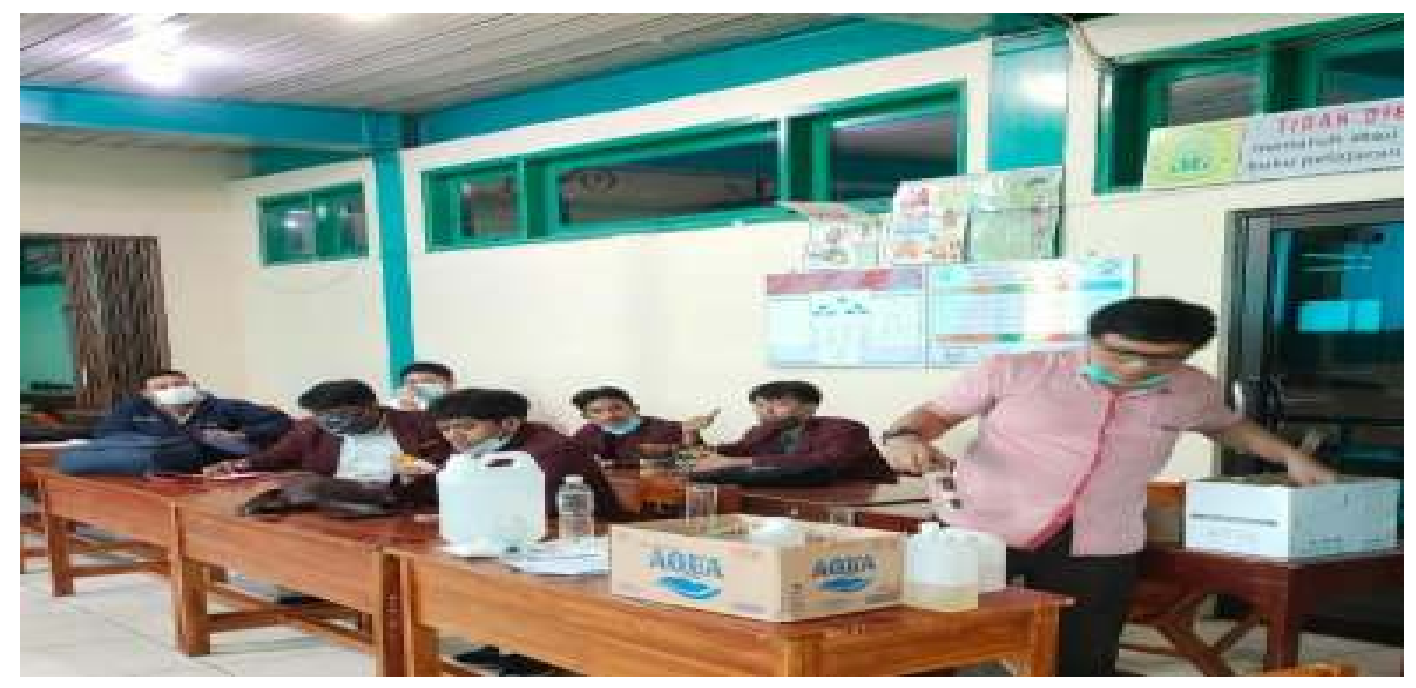

Kegiatan keempat / Selasa, 24 November 2020

Pengajuan Proposal PKM / Bertempat di STIH IBLAM dan diuji oleh dosen dan Ketua PKM STIH IBLAM

Kegiatan Kelima / Kamis, 26 November 2020 Bimbingan Pembuatan Produk PKM (Ketua PWPM DKI Jakarta Apt. Guntur S.R, S.,Si.)

Pembuatan produk sabun tangan cair dan pengemasannya, yang akan dipandu oleh mitra PWPM DKI Jakarta.

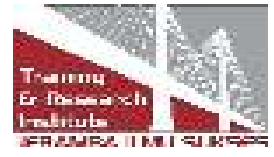




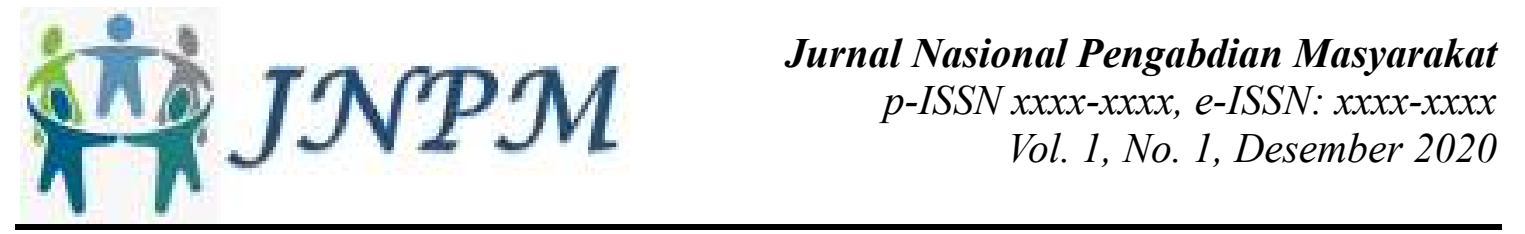

Gambar 4

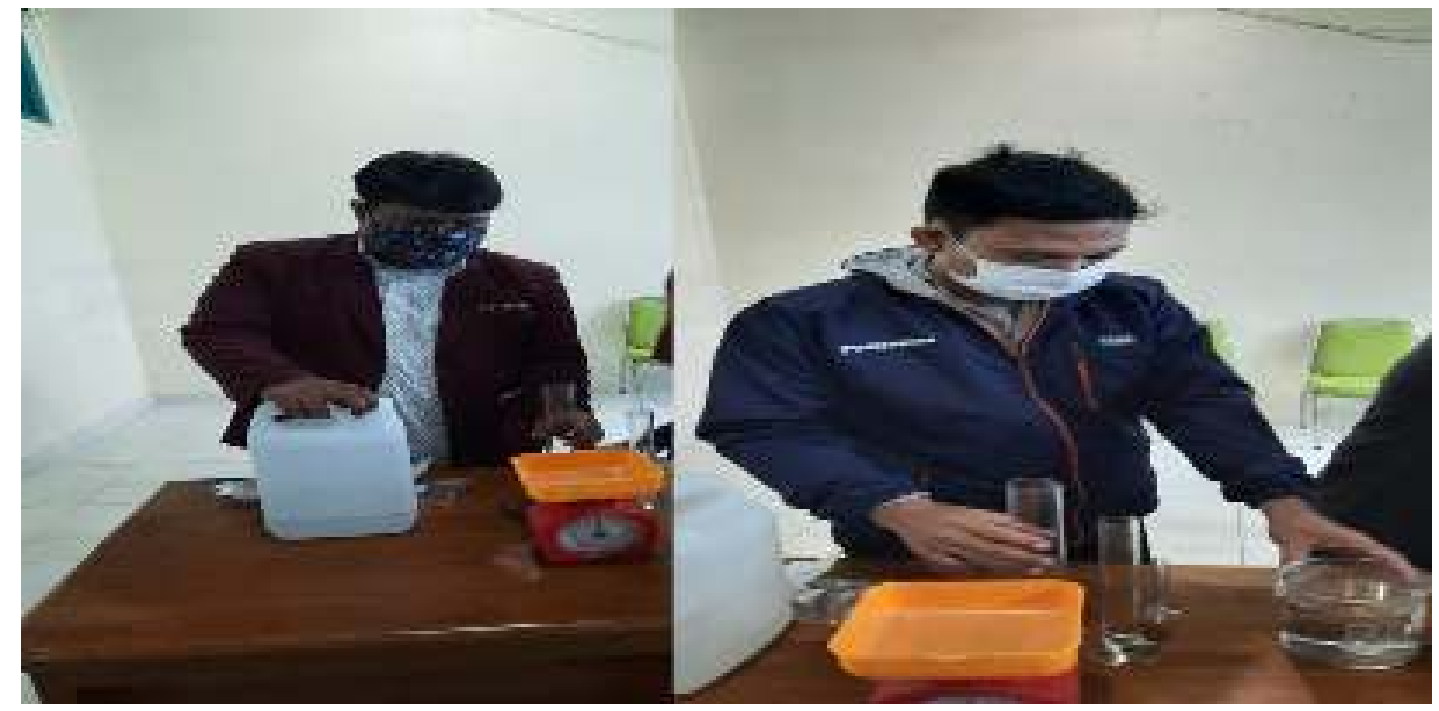

Gambar 5

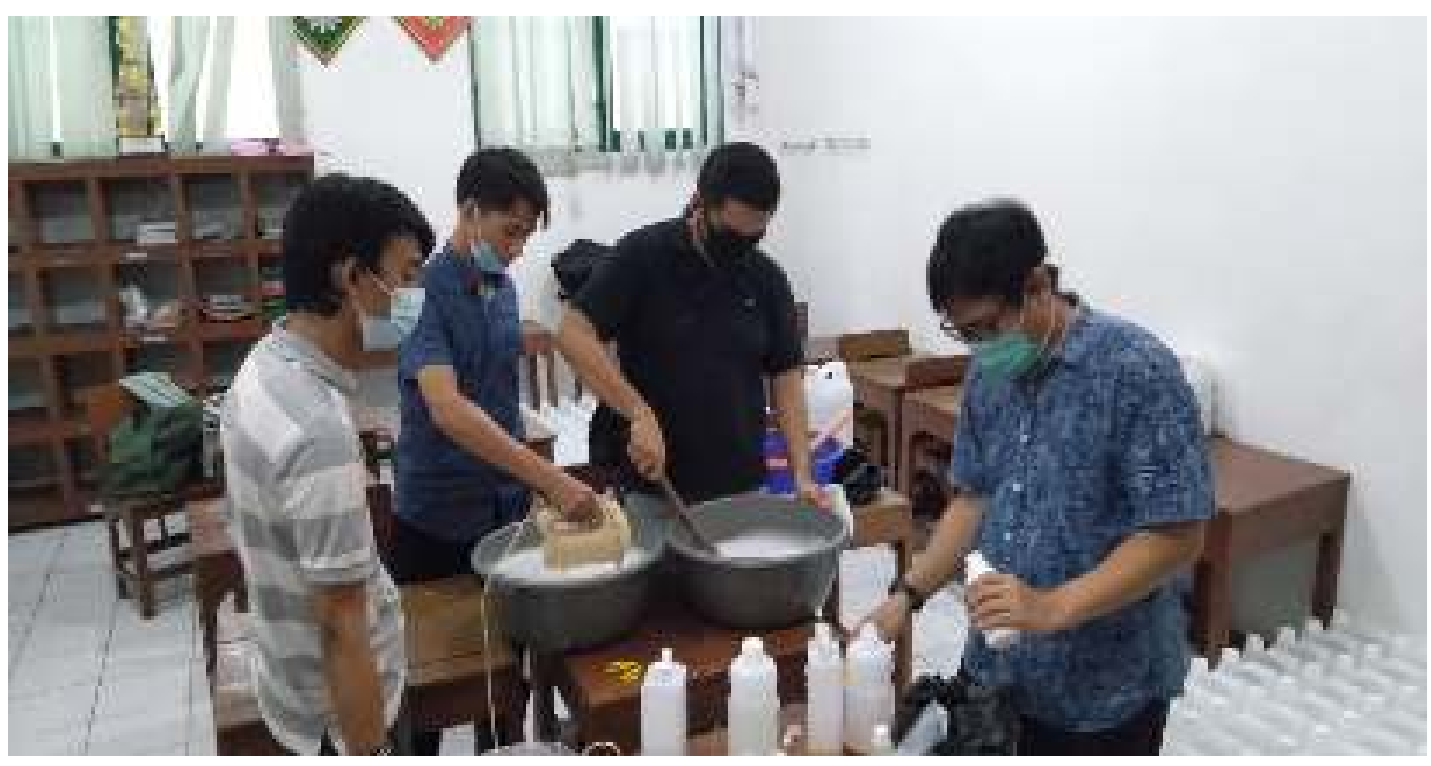

\section{Kegiatan Keenam}

\section{Laporan Harian kegiatan PKM}

Laporan Harian kegiatan PKM ini akan kami buat dalam bentuk jurnal dan kami laporkan kepada Ketua PKM STIH IBLAM

Published by:

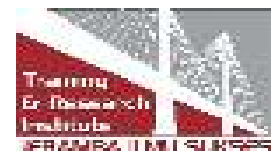




\section{Kegiatan Ketujuh}

\section{Seminar Laporan Akhir kegiatan PKM}

Kami akan memaparkan laporan kegiatan selama PKM di acara seminar yang akan diselenggarakan ditempat mitra kami yaitu PCM Kramat Jati, Jakarta Timur, DKI Jakarta.

\section{Kesimpulan}

Hasil yang didapat dari kegiatan ini adalah pemanfaatan botol plastik daur ulang atau bekas sebagai kemasan sabun tangan ini dapat mengurangi pembiayaan dibandingkan menggunakan botol plastik sekali pakai serta menjaga lingkungan dari sampah plastik yang sulit untuk terurai. Memberdayakan masyarakat untuk keberlangsungan perekonomian dan sosial masyarakat, serta menjalankan protokol kesehatan dalam upaya pencegahan dan pengendalian COVID-19 sesuai dengan Keputusan Menteri Kesehatan Republik Indonesia Nomor Hk.01.07/Menkes/382/2020 Tentang Protokol Kesehatan Bagi Masyarakat Di Tempat Dan Fasilitas Umum Dalam Rangka Pencegahan Dan Pengendalian Corona Virus Disease 2019 (Covid-19).

\section{Referensi}

Direktorat riset dan pengabdian masyarakat. 2020. Panduan penelitian dan pengabdian masyarakat edisi XIII. Jakarta : Direktorat Riset dan Pengabdian Masyarakat, Deputi Bidang Penguatan Riset dan Pengembangan, Kementerian Riset dan Teknologi / Badan Riset dan Inovasi Nasional.

Intan Purwatianingsih Sihadi, Sifrid S. Pangemanan, Hendrik Gamaliel. 2018. Identifikasi Kendala Dalam Proses Produksi Dan Dampaknya Terhadap Biaya Produksi Pada UD. Risky. Jurnal Riset Akuntansi Going Concern. 13(4) : 602-609 .

Hijrah Purnama Putra, Yebi Yuriandala. 2010. Studi Pemanfaatan Sampah Plastik Menjadi Produk dan Jasa Kreatif. Jurnal Sains dan Teknologi Lingkungan. Volume 2, Nomor 1, Halaman 21-31

Cenadi, Christine Suharto. 2000. Peranan Desain Kemasan dalam Dunia Pemasaran. Jurnal Nirmana Vol 2. No. 1, Januari 2000.

https://kemenperin.go.id. Bisnis Indonesia. 2019. Kemasan Daur Ulang Jadi Solusi diakses pada 11 Desember 2020

https://www.jurnal.id. Jurnal entrepreneur. 2017. Pengertian Keuntungan-

Menggunakan Sistem ERP diakses pada 13 Desember 2020

https://cloud.google.com. Inside Google cloud. 2020. Membantu industri manufaktur selama dan setelah pandemi COVID-19 diakses pada 11 Desembe 2020

Undang-Undang Dasar 1945, Pasal 28H ayat (1)

Undang-Undang Nomor. 36 Tahun 2014 Tentang Tenaga Kesehatan namun saat ini belum ada peraturan pelaksanaan dan petunjuk teknis Undang-undang Tenaga kesehatan dan

Published by:

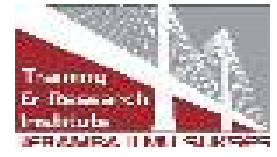


undang-undang lainnya yang mengatur tentang perlindungan hukum dan keselamatan kerja bagi Tenaga kesehatan.

Undang-Undang Nomor. 6 Tahun 2018 Tentang Kekarantinaan Kesehatan merupakan wewenang absolutPemerintah Pusat

Peraturan Pemerintah Nomor. 21 Tahun 2020 Tentang Pembatasan Sosial Berskala Besar dalam rangka Percepatan Penanganan Corona Virus Disease (COVID-19).

Intruksi Presiden Nomor. 4 Tahun 2020 Tentang refocussing kegiatan, realokasi anggaran serta pengadaan barang dan jasa dalam rangka percepatan penanganan Corona Virus Disease 2019(COVID-19).

Keputusan Menteri Kesehatan Republik Indonesia Nomor Hk.01.07/Menkes/382/2020 Tentang Protokol Kesehatan Bagi Masyarakat Di Tempat Dan Fasilitas Umum Dalam Rangka Pencegahan Dan Pengendalian Corona Virus Disease 2019 (Covid-19)

\section{Copyrights}

Copyright for this article is retained by the author(s), with first publication rights granted to the journal.

This is an open-access article distributed under the terms and conditions of the Creative Commons Attribution license (http://creativecommons.org/licenses/by/4.0/)

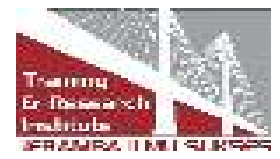

